\title{
Chemostratigraphy and provenance of clays and other non-carbonate minerals in chalks of Campanian age (Upper Cretaceous) from Sussex, southern England
}

\author{
D. S. WRAY ${ }^{1, *}$ AND C. V. JEANS ${ }^{2}$ \\ ${ }^{1}$ School of Science, The University of Greenwich, Pembroke, Chatham Maritime, Kent, ME4 4TB, UK, and \\ ${ }^{2}$ Department of Geography, University of Cambridge, Downing Place, Cambridge, CB2 3EQ, UK
}

(Received 3 December 2013; revised 11 February 2014; editor: Harry Shaw)

\begin{abstract}
Geochemical analysis of acid-insoluble residues derived from white chalks and marl seams of Campanian age from Sussex, UK, has been undertaken. All display a broadly similar $<2 \mu \mathrm{m}$ mineralogical composition consisting of smectite or smectite-rich illite-smectite with subordinate illite and minor amounts of talc. Plots of $\mathrm{K}_{2} \mathrm{O} / \mathrm{Al}_{2} \mathrm{O}_{3}$ and $\mathrm{TiO}_{2} / \mathrm{Al}_{2} \mathrm{O}_{3}$ indicate that most marl seams have an acid-insoluble residue composition which is slightly different to that of the over- and underlying white chalk, implying that marl seams are primary sedimentary features not formed through white chalk dissolution. On the basis of a negative Eu anomaly and trace element geochemistry one marl seam, the Old Nore Marl, is considered to be volcanically derived and best classified as a bentonite; it is considered to correlate with the bentonite M1 of the north German succession.
\end{abstract}

KEYwords: Cretaceous, bentonite, chemostratigraphy, Campanian, mineralogy, sediment provenance, Sussex.

The aim of this paper is to investigate the geochemistry of the non-carbonate fraction of marly and white chalks as found at Peacehaven Steps on the Sussex coast. The data will be used to examine the previously published interpretation of the Old Nore Marl as representing a bentonite (Mortimore et al., 2001; p. 214). It will also discuss the origin of clay-rich beds higher in the succession and the non-carbonate fraction of the interbedded white chalks.

The Peacehaven Steps succession is of Campanian age (O. pilula to $G$ quadrata zones). It is a well known locality on the Sussex coast, in

* E-mail: d.wray@greenwich.ac.uk

DOI: 10.1180/claymin.2014.049.2.10 part because the steps allow a rapid traverse of the chalk sequence whose bedding is near-horizontal at this point. The stratigraphy of the succession and its relationship to the remainder of the Anglo-Paris Basin is well documented (Mortimore, 1986; Mortimore et al., 2001). The early Campanian is distinctive in that chalks of this age in southern England contain a number of laterally persistent more clay-rich beds, often termed "marl seams" which are more abundant at this level than in the underlying beds of Santonian age. The origin and correlation of these Campanian marls was first discussed in a series of papers by Brydone (Brydone, 1914a,b) who recognized the widespread lateral continuity of individual marl seams and argued, based on their lateral persistence, that they represented altered volcanic ashfalls. 
TABLE 1. Geochemical data used in this study; all data are derived from acid-insoluble residues.

\begin{tabular}{|c|c|c|c|c|c|c|c|c|c|c|}
\hline & $\mathrm{SiO}_{2}$ & $\mathrm{TiO}_{2}$ & $\mathrm{Al}_{2} \mathrm{O}_{3}$ & $\mathrm{Fe}_{2} \mathrm{O}_{3}(\mathrm{t})$ & $\mathrm{MnO}$ & $\mathrm{MgO}$ & $\mathrm{CaO}$ & $\mathrm{Na}_{2} \mathrm{O}$ & $\mathrm{K}_{2} \mathrm{O}$ & $\mathrm{P}_{2} \mathrm{O}_{5}$ \\
\hline \multicolumn{11}{|c|}{ Oxide wt.\% } \\
\hline PHS 65 & 48.77 & 0.63 & 14.40 & 11.12 & 0.026 & 2.81 & 5.76 & 0.13 & 2.31 & 2.17 \\
\hline PHS 64 & 56.49 & 0.62 & 15.20 & 4.18 & 0.008 & 3.13 & 4.56 & 0.12 & 2.47 & 1.31 \\
\hline PHS 63 & 55.70 & 0.61 & 15.22 & 4.55 & 0.012 & 2.99 & 4.47 & 0.12 & 2.43 & 1.57 \\
\hline PHS 62 & 55.81 & 0.65 & 16.31 & 4.08 & 0.464 & 3.21 & 5.78 & 0.13 & 2.45 & 2.04 \\
\hline PHS 61 & 54.70 & 0.67 & 16.80 & 8.16 & 0.330 & 3.25 & 4.20 & 0.12 & 2.47 & 1.57 \\
\hline PHS 60 & 54.74 & 0.67 & 16.91 & 4.17 & 0.007 & 3.31 & 5.51 & 0.14 & 2.59 & 1.92 \\
\hline PHS 59 & 55.87 & 0.67 & 17.20 & 4.98 & 0.011 & 3.46 & 4.43 & 0.13 & 2.46 & 1.41 \\
\hline PHS 58 & 55.43 & 0.72 & 16.69 & 3.76 & 0.007 & 3.33 & 6.78 & 0.17 & 2.52 & 2.83 \\
\hline PHS 57 & 54.04 & 0.64 & 17.01 & 3.86 & 0.006 & 3.85 & 7.14 & 0.12 & 1.77 & 2.75 \\
\hline PHS 56 & 50.66 & 0.64 & 14.96 & 4.25 & 0.007 & 3.16 & 8.66 & 0.17 & 2.44 & 3.86 \\
\hline PHS 55 & 50.48 & 0.67 & 15.38 & 7.35 & 0.011 & 3.24 & 6.16 & 0.14 & 2.49 & 2.62 \\
\hline PHS 54 & 54.81 & 0.67 & 17.28 & 3.90 & 0.006 & 3.82 & 5.90 & 0.12 & 2.09 & 2.10 \\
\hline PHS 53 & 51.14 & 0.64 & 15.04 & 3.61 & 0.007 & 3.17 & 7.64 & 0.16 & 2.34 & 3.06 \\
\hline PHS 52 & 57.22 & 0.72 & 17.49 & 4.67 & 0.007 & 3.36 & 5.07 & 0.15 & 2.69 & 2.23 \\
\hline PHS 51 & 57.53 & 0.72 & 17.49 & 4.91 & 0.007 & 3.31 & 4.72 & 0.14 & 2.74 & 2.08 \\
\hline PHS 50 & 60.26 & 0.72 & 18.44 & 3.94 & 0.006 & 3.44 & 2.63 & 0.12 & 2.78 & 0.65 \\
\hline PHS 49 & 57.96 & 0.66 & 16.93 & 4.61 & 0.006 & 3.34 & 4.28 & 0.13 & 2.75 & 1.80 \\
\hline PHS 48 & 57.43 & 0.66 & 16.82 & 4.70 & 0.006 & 3.29 & 4.60 & 0.14 & 2.66 & 1.98 \\
\hline PHS 47 & 57.48 & 0.67 & 17.32 & 4.83 & 0.007 & 3.41 & 4.19 & 0.14 & 2.73 & 1.76 \\
\hline PHS 46 & 59.14 & 0.67 & 18.03 & 5.19 & 0.007 & 3.50 & 3.22 & 0.12 & 2.71 & 1.05 \\
\hline PHS 45 & 61.23 & 0.67 & 19.11 & 3.92 & 0.006 & 3.59 & 2.33 & 0.11 & 2.66 & 0.30 \\
\hline PHS 44 & 61.46 & 0.63 & 19.31 & 4.34 & 0.007 & 3.64 & 2.83 & 0.10 & 2.49 & 0.66 \\
\hline PHS 43 & 58.59 & 0.67 & 18.28 & 3.57 & 0.007 & 3.40 & 5.03 & 0.15 & 2.63 & 2.15 \\
\hline PHS 42 & 61.20 & 0.75 & 18.96 & 3.87 & 0.006 & 3.54 & 2.66 & 0.13 & 2.88 & 0.67 \\
\hline PHS 41 & 56.20 & 0.64 & 16.68 & 4.34 & 0.007 & 3.30 & 5.72 & 0.16 & 2.50 & 2.78 \\
\hline PHS 40 & 54.57 & 0.63 & 16.28 & 4.29 & 0.006 & 3.17 & 6.60 & 0.17 & 2.43 & 3.36 \\
\hline PHS 39 & 54.77 & 0.62 & 16.26 & 5.19 & 0.006 & 3.24 & 5.11 & 0.15 & 2.51 & 2.42 \\
\hline PHS 38 & 55.17 & 0.64 & 16.45 & 5.53 & 0.007 & 3.24 & 4.93 & 0.14 & 2.54 & 2.30 \\
\hline PHS 37 & 57.37 & 0.64 & 17.16 & 3.71 & 0.006 & 3.44 & 4.42 & 0.14 & 2.55 & 1.80 \\
\hline PHS 36 & 56.44 & 0.63 & 17.30 & 3.78 & 0.007 & 3.53 & 5.10 & 0.14 & 2.51 & 2.24 \\
\hline PHS 35 & 57.41 & 0.65 & 18.17 & 4.72 & 0.007 & 3.52 & 4.69 & 0.13 & 2.52 & 1.95 \\
\hline PHS 34 & 56.35 & 0.60 & 17.15 & 4.59 & 0.008 & 3.55 & 5.44 & 0.14 & 2.54 & 2.50 \\
\hline PHS 33 & 57.32 & 0.64 & 17.44 & 3.92 & 0.006 & 3.41 & 5.24 & 0.15 & 2.55 & 2.29 \\
\hline PHS 32 & 57.36 & 0.70 & 17.55 & 4.81 & 0.006 & 3.48 & 3.91 & 0.13 & 2.68 & 1.51 \\
\hline PHS 31 & 58.82 & 0.68 & 18.11 & 4.19 & 0.006 & 3.42 & 3.69 & 0.13 & 2.66 & 1.29 \\
\hline PHS 30 & 57.06 & 0.65 & 16.80 & 5.58 & 0.006 & 3.28 & 3.75 & 0.12 & 2.51 & 1.45 \\
\hline PHS 29 & 58.23 & 0.63 & 17.17 & 3.54 & 0.006 & 3.39 & 4.67 & 0.15 & 2.45 & 1.95 \\
\hline PHS 28 & 53.97 & 0.58 & 15.20 & 4.95 & 0.006 & 3.04 & 6.46 & 0.16 & 2.27 & 3.34 \\
\hline PHS 27 & 55.17 & 0.61 & 15.90 & 5.35 & 0.006 & 3.15 & 5.12 & 0.14 & 2.46 & 2.46 \\
\hline PHS 26 & 57.08 & 0.64 & 16.83 & 5.39 & 0.006 & 3.34 & 3.61 & 0.13 & 2.57 & 1.41 \\
\hline PHS 25 & 54.94 & 0.62 & 16.45 & 4.40 & 0.006 & 3.23 & 5.84 & 0.15 & 2.41 & 2.81 \\
\hline PHS 24 & 59.31 & 0.67 & 17.43 & 4.00 & 0.007 & 3.77 & 2.54 & 0.11 & 2.71 & 0.59 \\
\hline PHS 23 & 61.12 & 0.68 & 18.14 & 4.44 & 0.005 & 3.55 & 2.12 & 0.10 & 2.57 & 0.24 \\
\hline PHS 22 & 57.78 & 0.64 & 17.18 & 3.74 & 0.006 & 3.44 & 4.37 & 0.13 & 2.49 & 1.79 \\
\hline PHS 21 & 59.05 & 0.66 & 17.61 & 4.92 & 0.006 & 3.58 & 2.99 & 0.12 & 2.52 & 0.92 \\
\hline PHS 20 & 64.39 & 0.55 & 14.60 & 3.65 & 0.005 & 2.83 & 3.64 & 0.12 & 2.17 & 1.49 \\
\hline PHS 19 & 54.40 & 0.59 & 16.14 & 3.86 & 0.006 & 3.20 & 6.65 & 0.16 & 2.32 & 3.28 \\
\hline PHS 18 & 56.28 & 0.61 & 16.76 & 4.85 & 0.006 & 3.30 & 4.75 & 0.14 & 2.40 & 2.04 \\
\hline PHS 17 & 58.15 & 0.66 & 17.24 & 4.54 & 0.007 & 3.53 & 3.84 & 0.13 & 2.63 & 1.48 \\
\hline PHS 16 & 60.23 & 0.69 & 18.11 & 3.82 & 0.006 & 3.62 & 3.71 & 0.14 & 2.68 & 1.29 \\
\hline PHS 15 & 63.22 & 0.62 & 18.15 & 3.53 & 0.005 & 3.85 & 2.49 & 0.11 & 2.37 & 0.49 \\
\hline PHS 14 & 59.32 & 0.65 & 18.19 & 5.48 & 0.005 & 3.36 & 2.72 & 0.11 & 2.43 & 0.69 \\
\hline PHS 13 & 59.26 & 0.67 & 18.00 & 4.13 & 0.006 & 3.32 & 3.55 & 0.13 & 2.60 & 1.23 \\
\hline PHS 12 & 55.39 & 0.59 & 15.22 & 3.55 & 0.006 & 2.97 & 7.68 & 0.18 & 2.27 & 3.91 \\
\hline PHS 11 & 58.44 & 0.64 & 16.15 & 4.39 & 0.005 & 3.13 & 4.51 & 0.14 & 2.38 & 1.93 \\
\hline PHS 10 & 64.81 & 0.52 & 12.83 & 3.66 & 0.005 & 2.50 & 5.25 & 0.14 & 1.86 & 2.55 \\
\hline PHS 9 & 60.18 & 0.66 & 17.92 & 3.63 & 0.006 & 3.48 & 3.79 & 0.13 & 2.37 & 1.30 \\
\hline
\end{tabular}


TABLE 1 (contd.).

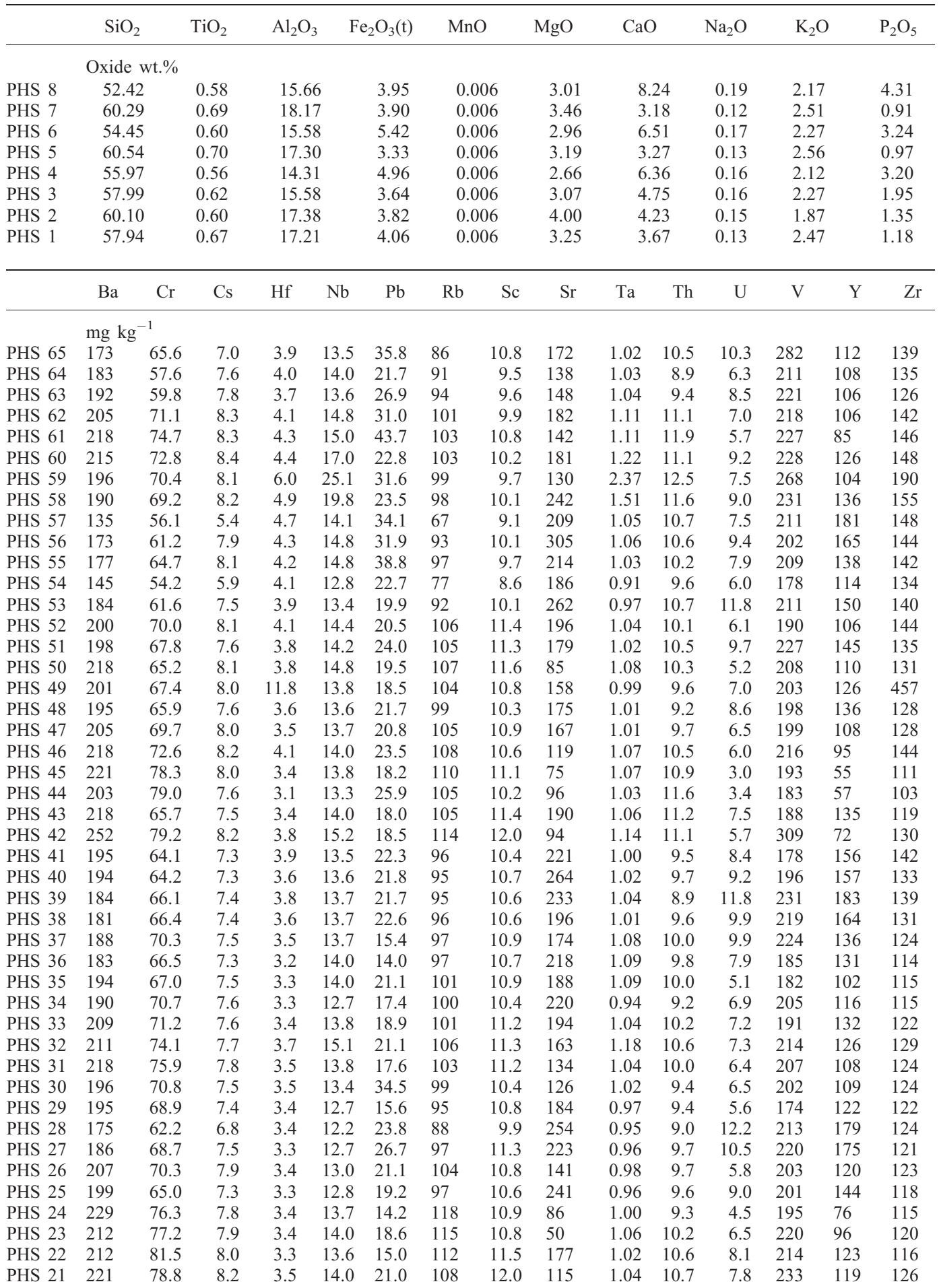


TABLE 1. (contd.).

\begin{tabular}{llllllllrlllllll}
\hline & $\mathrm{Ba}$ & $\mathrm{Cr}$ & $\mathrm{Cs}$ & $\mathrm{Hf}$ & $\mathrm{Nb}$ & $\mathrm{Pb}$ & $\mathrm{Rb}$ & $\mathrm{Sc}$ & $\mathrm{Sr}$ & $\mathrm{Ta}$ & $\mathrm{Th}$ & $\mathrm{U}$ & $\mathrm{V}$ & $\mathrm{Y}$ & $\mathrm{Zr}$ \\
\hline \multicolumn{3}{c}{$\mathrm{mg} \mathrm{kg}^{-1}$} & & & & & & & & & & & & & \\
PHS 20 & 178 & 59.2 & 6.7 & 2.7 & 11.1 & 17.4 & 88 & 9.5 & 134 & 0.81 & 8.1 & 7.0 & 174 & 100 & 99 \\
PHS 19 & 185 & 64.1 & 7.5 & 3.0 & 12.2 & 18.9 & 95 & 10.4 & 255 & 0.92 & 9.0 & 11.2 & 196 & 144 & 106 \\
PHS 18 & 190 & 75.5 & 7.9 & 3.3 & 13.0 & 22.0 & 98 & 10.2 & 169 & 0.98 & 8.9 & 9.5 & 208 & 139 & 121 \\
PHS 17 & 204 & 76.5 & 8.5 & 3.4 & 14.1 & 16.9 & 106 & 11.5 & 135 & 0.99 & 9.6 & 5.1 & 201 & 95 & 123 \\
PHS 16 & 219 & 89.7 & 8.7 & 3.6 & 14.7 & 14.3 & 111 & 12.6 & 128 & 1.04 & 11.0 & 6.6 & 237 & 108 & 132 \\
PHS 15 & 190 & 84.5 & 7.8 & 3.2 & 13.5 & 13.0 & 99 & 10.3 & 80 & 0.96 & 10.2 & 4.2 & 199 & 64 & 115 \\
PHS 14 & 206 & 61.9 & 7.4 & 3.2 & 14.8 & 21.2 & 98 & 10.5 & 75 & 0.98 & 9.1 & 5.9 & 200 & 83 & 119 \\
PHS 13 & 239 & 70.5 & 7.6 & 3.4 & 15.1 & 15.5 & 104 & 11.1 & 120 & 0.99 & 9.6 & 7.0 & 201 & 92 & 125 \\
PHS 12 & 179 & 63.1 & 6.9 & 1.3 & 13.9 & 17.4 & 89 & 9.6 & 292 & 0.91 & 8.6 & 16.4 & 220 & 155 & 63 \\
PHS 11 & 198 & 72.4 & 7.5 & 3.0 & 15.7 & 21.6 & 98 & 10.2 & 165 & 0.99 & 9.3 & 10.3 & 243 & 118 & 128 \\
PHS 10 & 157 & 64.5 & 6.0 & 2.8 & 12.8 & 15.2 & 76 & 9.5 & 204 & 0.82 & 8.5 & 8.1 & 181 & 111 & 114 \\
PHS 9 & 207 & 95.3 & 8.0 & 3.5 & 17.2 & 15.8 & 103 & 10.9 & 137 & 1.04 & 11.0 & 4.5 & 229 & 70 & 139 \\
PHS 8 & 176 & 68.2 & 6.8 & 1.2 & 15.5 & 18.1 & 89 & 11.6 & 324 & 0.93 & 10.0 & 11.1 & 187 & 140 & 66 \\
PHS 7 & 215 & 87.5 & 8.1 & 3.8 & 19.4 & 17.9 & 108 & 10.6 & 110 & 1.11 & 11.2 & 3.7 & 232 & 54 & 155 \\
PHS 6 & 186 & 71.4 & 7.4 & 1.4 & 20.9 & 30.0 & 96 & 11.1 & 263 & 1.04 & 10.5 & 9.8 & 205 & 134 & 79 \\
PHS 5 & 222 & 78.3 & 8.5 & 4.2 & 23.2 & 12.2 & 109 & 10.9 & 104 & 1.21 & 10.8 & 3.9 & 199 & 71 & 166 \\
PHS 4 & 175 & 55.4 & 6.4 & 1.0 & 25.0 & 27.5 & 83 & 9.3 & 243 & 1.16 & 9.8 & 11.5 & 179 & 172 & 57 \\
PHS 3 & 173 & 63.7 & 7.0 & 8.7 & 48.0 & 18.0 & 92 & 10.0 & 175 & 4.20 & 11.6 & 7.1 & 201 & 138 & 238 \\
PHS 2 & 132 & 66.9 & 4.3 & 16.8 & 47.9 & 32.3 & 68 & 7.0 & 134 & 8.93 & 24.8 & 4.3 & 186 & 82 & 385 \\
PHS 1 & 206 & 73.0 & 7.9 & 6.9 & 34.6 & 15.2 & 104 & 10.6 & 122 & 2.08 & 11.0 & 5.1 & 172 & 114 & 216
\end{tabular}

\begin{tabular}{|c|c|c|c|c|c|c|c|c|c|c|c|c|c|c|}
\hline & $\mathrm{La}$ & $\mathrm{Ce}$ & $\operatorname{Pr}$ & $\mathrm{Nd}$ & $\mathrm{Sm}$ & $\mathrm{Eu}$ & $\mathrm{Gd}$ & $\mathrm{Tb}$ & Dy & Ho & Er & $\mathrm{Tm}$ & $\mathrm{Yb}$ & $\mathrm{Lu}$ \\
\hline \multicolumn{15}{|c|}{$\mathrm{mg} \mathrm{kg}^{-1}$} \\
\hline HS 65 & 85.7 & 68.5 & 16.9 & 68.7 & 12.6 & 2.97 & 14.0 & 1.95 & 11.2 & 2.39 & 5.70 & 0.70 & 3.48 & 0.47 \\
\hline HS 64 & 83.5 & 66.1 & & 65.3 & & & & & 10.9 & & & .65 & & 0.43 \\
\hline HS 63 & 79.5 & 65.6 & & 62.7 & & & & & & & & 64 & & 0.42 \\
\hline HS 62 & 82.8 & 72.0 & & 67.1 & 12. & 2.90 & & & 10.8 & & & .66 & & 0.45 \\
\hline & 73.8 & & & 59.0 & & & & & & & & & & 0.42 \\
\hline S 60 & 95.1 & 80.7 & & 76.7 & & & & & 12.7 & & & & & 0.51 \\
\hline S 5 & & 74.5 & & 66.5 & & & & & 10.8 & & & & & 0.48 \\
\hline HS 58 & 100.6 & 84.1 & & & & & & & & & & & & 0.53 \\
\hline 5 & 1 & 119. & & 110. & & & & & & & & & & \\
\hline 5 & 11 & & & & & & & & & & & & & .59 \\
\hline & & & & & & & & & & & & & & .51 \\
\hline & 77.8 & & & & & & & & & & & & & 0.42 \\
\hline S 5 & 95.1 & & & & & & & & & & & & & .52 \\
\hline & & & & & & & & & & & & & & 0.45 \\
\hline & 106 & & & & & & & & & & & & & 0.52 \\
\hline T & & & & & & & & & & & & & & 0.48 \\
\hline & & & & & & & & & & & & & & .47 \\
\hline & 96 & & & & & & & & & & & & & 0.49 \\
\hline & & & & & & & & & & & & & & 0.43 \\
\hline & & & & & & & & & & & & & & 0.41 \\
\hline & 52. & & & & & & & & & & & 43 & & 0.32 \\
\hline & & & & & & & & & & & & & & 0.31 \\
\hline & 104 & & & & & & 16 & & 13.6 & & & 83 & & 0.53 \\
\hline & & & & & & & & & & & & 53 & 2.76 & 0.38 \\
\hline & & & & & & & & & & & & & & \\
\hline & & & & & & & & & & & & & & 0.57 \\
\hline & & & & & & & & & & & & & & .61 \\
\hline & & & & & & & & & & & & & & \\
\hline PHS 37 & 94. & 75. & & 75. & & & & 2.23 & & .79 & & 78 & & 0.51 \\
\hline & 92. & & & & & & & & & & & & & 0.48 \\
\hline & & & & & & & & & & & & & & \\
\hline PHS 3 & 82.4 & 69.4 & 15 & 65. & & & & & & & & & & 0.43 \\
\hline PHS 33 & 96.4 & 81.5 & 18.9 & 78.3 & 14.6 & 3.42 & 16.4 & 2.28 & 13.1 & 2.75 & 6.44 & 0.77 & 3.71 & 0.50 \\
\hline
\end{tabular}


TABLE 1. (contd.).

\begin{tabular}{|c|c|c|c|c|c|c|c|c|c|c|c|c|c|c|}
\hline & $\mathrm{La}$ & $\mathrm{Ce}$ & $\operatorname{Pr}$ & $\mathrm{Nd}$ & $\mathrm{Sm}$ & $\mathrm{Eu}$ & $\mathrm{Gd}$ & $\mathrm{Tb}$ & Dy & Но & Er & $\mathrm{Tm}$ & $\mathrm{Yb}$ & $\mathrm{Lu}$ \\
\hline \multicolumn{15}{|c|}{$\mathrm{mg} \mathrm{kg}^{-1}$} \\
\hline PHS 32 & 95.5 & 79.2 & 18.6 & 76.9 & 14.3 & 3.31 & 15.7 & 2.19 & 12.8 & 2.66 & 6.24 & 0.76 & 3.73 & 0.50 \\
\hline PHS 31 & 79.5 & 68.7 & 15.5 & 64.4 & 12.1 & 2.82 & 13.3 & 1.87 & 10.9 & 2.31 & 5.45 & 0.67 & 3.32 & 0.46 \\
\hline PHS 30 & 79.5 & 66.7 & 15.3 & 64.0 & 11.9 & 2.85 & 13.3 & 1.87 & 10.8 & 2.29 & 5.45 & 0.67 & 3.25 & 0.45 \\
\hline PHS 29 & 87.2 & 71.3 & 17.2 & 71.7 & 13.3 & 3.15 & 14.9 & 2.06 & 12.2 & 2.55 & 6.08 & 0.73 & 3.61 & 0.49 \\
\hline PHS 28 & 116.4 & 86.8 & 21.4 & 91.1 & 17.0 & 4.09 & 19.7 & 2.80 & 16.8 & 3.62 & 8.47 & 0.99 & 4.67 & 0.63 \\
\hline PHS 27 & 119.5 & 89.3 & 22.2 & 92.8 & 17.3 & 4.15 & 19.7 & 2.81 & 16.6 & 3.56 & 8.47 & 1.02 & 4.84 & 0.64 \\
\hline PHS 26 & 84.8 & 71.8 & 16.7 & 68.9 & 13.0 & 3.03 & 14.3 & 2.05 & 12.0 & 2.53 & 5.98 & 0.73 & 3.60 & 0.49 \\
\hline PHS 25 & 99.1 & 81.1 & 19.0 & 79.1 & 15.0 & 3.58 & 16.9 & 2.40 & 14.0 & 2.97 & 6.94 & 0.84 & 4.07 & 0.54 \\
\hline PHS 24 & 61.7 & 57.8 & 12.3 & 50.3 & 9.4 & 2.16 & 10.0 & 1.41 & 8.1 & 1.69 & 4.06 & 0.54 & 2.69 & 0.38 \\
\hline PHS 23 & 72.7 & 66.5 & 14.7 & 60.2 & 11.3 & 2.67 & 12.2 & 1.74 & 10.2 & 2.15 & 5.10 & 0.64 & 3.27 & 0.44 \\
\hline PHS 22 & 94.6 & 84.3 & 19.3 & 79.5 & 14.9 & 3.52 & 16.1 & 2.27 & 13.0 & 2.71 & 6.33 & 0.77 & 3.76 & 0.50 \\
\hline PHS 21 & 85.7 & 74.9 & 17.0 & 70.1 & 13.1 & 3.13 & 14.5 & 2.09 & 12.2 & 2.56 & 6.05 & 0.76 & 3.75 & 0.50 \\
\hline PHS 20 & 72.8 & 61.9 & 14.5 & 59.8 & 11.2 & 2.61 & 12.4 & 1.75 & 10.1 & 2.16 & 5.13 & 0.63 & 3.13 & 0.44 \\
\hline PHS 19 & 94.8 & 74.6 & 17.5 & 74.0 & 14.1 & 3.37 & 16.0 & 2.26 & 13.5 & 2.90 & 6.89 & 0.80 & 3.85 & 0.52 \\
\hline PHS 18 & 93.5 & 75.1 & 17.8 & 74.3 & 13.8 & 3.39 & 16.0 & 2.23 & 13.3 & 2.83 & 6.58 & 0.79 & 3.75 & 0.50 \\
\hline PHS 17 & 70.6 & 62.8 & 14.1 & 58.2 & 10.8 & 2.55 & 11.9 & 1.65 & 9.7 & 2.07 & 5.00 & 0.62 & 3.10 & 0.44 \\
\hline PHS 16 & 81.1 & 73.3 & 16.3 & 66.2 & 12.3 & 2.85 & 13.3 & 1.91 & 11.1 & 2.35 & 5.70 & 0.72 & 3.64 & 0.50 \\
\hline PHS 15 & 53.2 & 55.3 & 11.2 & 45.3 & 8.4 & 1.91 & 8.6 & 1.24 & 7.1 & 1.50 & 3.62 & 0.45 & 2.38 & 0.33 \\
\hline PHS 14 & 61.1 & 58.8 & 12.6 & 51.3 & 9.6 & 2.28 & 10.4 & 1.48 & 8.6 & 1.82 & 4.41 & 0.54 & 2.82 & 0.38 \\
\hline PHS 13 & 69.5 & 64.6 & 14.1 & 58.2 & 11.0 & 2.63 & 12.1 & 1.71 & 9.7 & 2.05 & 4.70 & 0.57 & 2.86 & 0.39 \\
\hline PHS 12 & 101.8 & 81.2 & 19.5 & 81.4 & 15.3 & 3.74 & 17.8 & 2.50 & 14.7 & 3.17 & 7.32 & 0.87 & 4.14 & 0.55 \\
\hline PHS 11 & 82.8 & 70.4 & 16.2 & 68.2 & 12.8 & 3.04 & 14.3 & 2.01 & 12.0 & 2.55 & 6.03 & 0.72 & 3.55 & 0.49 \\
\hline PHS 10 & 79.1 & 67.3 & 15.3 & 63.6 & 11.9 & 2.87 & 13.3 & 1.89 & 11.1 & 2.37 & 5.61 & 0.67 & 3.32 & 0.44 \\
\hline PHS 9 & 60.2 & 60.4 & 12.3 & 49.0 & 9.1 & 2.01 & 9.3 & 1.34 & 7.8 & 1.65 & 3.95 & 0.53 & 2.81 & 0.39 \\
\hline PHS 8 & 95.5 & 82.8 & 18.1 & 75.4 & 14.3 & 3.41 & 16.3 & 2.34 & 13.7 & 2.93 & 6.87 & 0.81 & 3.94 & 0.53 \\
\hline PHS 7 & 45.6 & 51.0 & 9.5 & 37.8 & 7.1 & 1.58 & 7.1 & 1.03 & 6.1 & 1.27 & 3.17 & 0.44 & 2.35 & 0.34 \\
\hline PHS 6 & 91.2 & 78.0 & 17.4 & 72.8 & 13.5 & 3.18 & 15.5 & 2.24 & 13.1 & 2.86 & 6.67 & 0.81 & 3.93 & 0.53 \\
\hline PHS 5 & 53.5 & 54.7 & 10.9 & 43.9 & 8.2 & 1.86 & 8.8 & 1.26 & 7.5 & 1.63 & 3.98 & 0.52 & 2.78 & 0.40 \\
\hline PHS 4 & 108.9 & 89.8 & 20.8 & 88.0 & 16.5 & 3.83 & 19.4 & 2.79 & 16.4 & 3.59 & 8.26 & 0.97 & 4.52 & 0.60 \\
\hline PHS 3 & 102.0 & 102.4 & 21.4 & 88.1 & 17.1 & 3.41 & 18.3 & 2.67 & 15.3 & 3.16 & 7.30 & 0.90 & 4.31 & 0.58 \\
\hline PHS 2 & 69.9 & 101.4 & 18.1 & 73.2 & 14.7 & 2.23 & 13.7 & 2.00 & 11.0 & 2.16 & 4.94 & 0.61 & 3.10 & 0.42 \\
\hline PHS 1 & 79.3 & 77.4 & 15.9 & 66.1 & 12.7 & 2.81 & 14.2 & 2.04 & 12.0 & 2.53 & 5.96 & 0.72 & 3.61 & 0.50 \\
\hline
\end{tabular}

In the white chalk succession of the Anglo-Paris Basin and eastern England marl seams are most abundant in beds of Turonian and early Coniacian age and here they have been extensively studied (Pacey, 1984; Deconinck \& Chamley, 1995; Wray \& Wood, 1998; Wray, 1999). Previous work has demonstrated that Turonian-early Coniacian marl seams have either a detrital origin, or are bentonites derived from the alteration of distal volcanic ash (Wray, 1999). This work built on earlier mineralogical studies on Turonian successions in the Lower Saxony area of Germany where bentonites were first described (Dorn \& Bräutigam, 1959; Seibertz \& Vortisch, 1979; Ernst et al., 1983; Wray, 1995; Wray et al., 1995; Wray \& Wood, 1995; Wray et al., 1996; Wray \& Wood, 2002). Wray (1999) demonstrated that it is possible to correlate all the Turonian marl seams of volcanogenic origin in the Anglo-Paris Basin with ones in the successions of both eastern England and northern Germany, facilitating a field applicable chronostratigraphic framework for the Turonian and Coniacian Stages. In contrast, whilst it is possible to correlate detrital marl seams within a region, it has not been possible to confidently correlate them between regions.

Although data have been generated from younger marl seams by Wray, none of this information has been formally published; instead, specific pieces of information have entered the literature in the form of personal communications (e.g. Mortimore et al., 2001; p. 214) which is somewhat unsatisfactory. One aim of this piece of work is to formally publish the underlying evidence for some of these statements.

White chalks of lower Campanian age are predominantly composed of calcium carbonate and usually only comprise at most $1-2 \%$ non-carbonate 


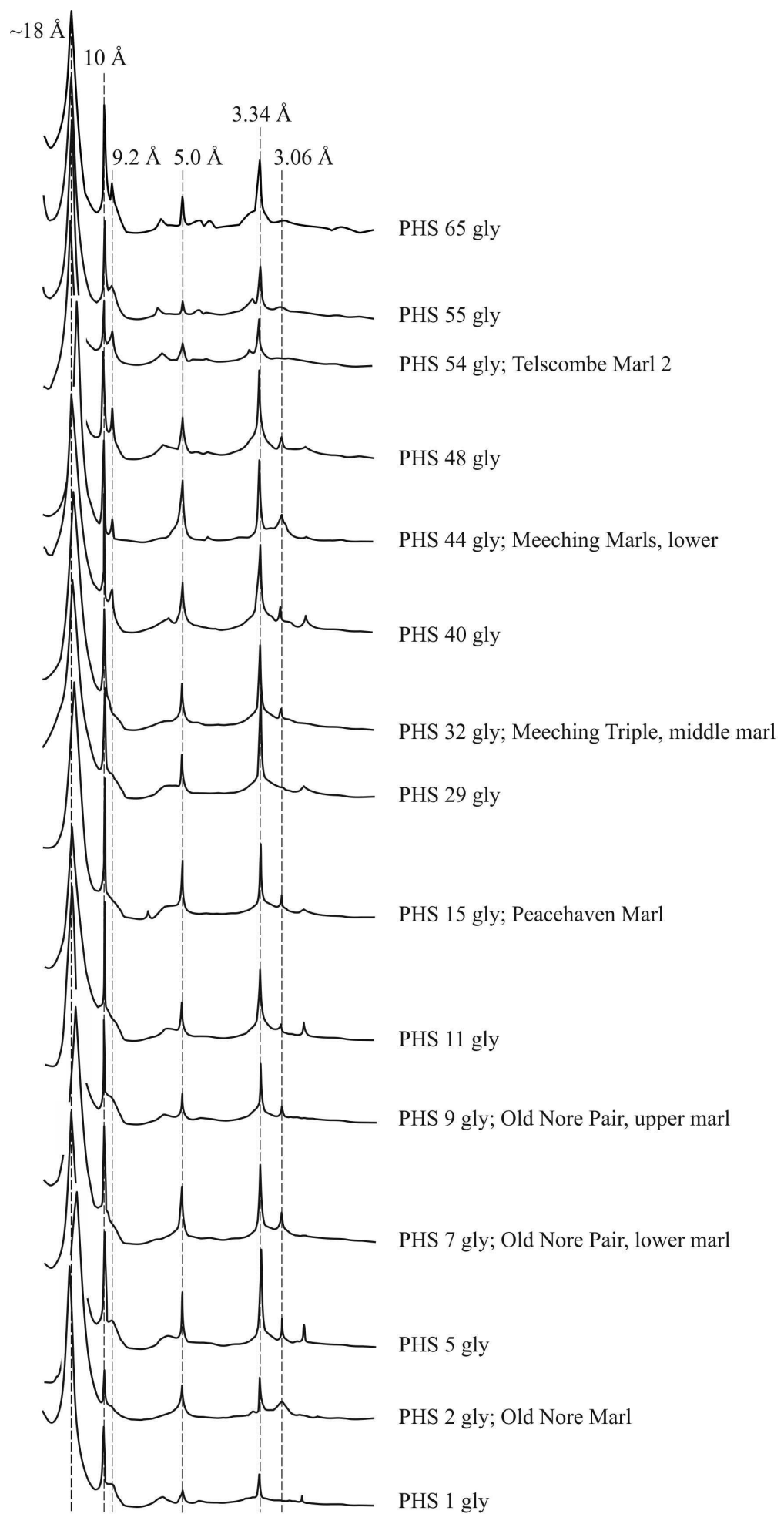


minerals; even many of the marl seams only contain in the region of $3-10 \%$ non-carbonate minerals. Such a low proportion of non-carbonate material tests the limits of detection of even the most modern analytical systems and hence we elected to dissolve away the carbonate fraction of all samples and subject the residual non-carbonate fraction to geochemical testing. This approach enables the direct comparison of the non-carbonate fraction present in different lithologies without the need to compensate for variable carbonate content.

Previous work has investigated the non-carbonate mineralogy of white chalks of comparable age from elsewhere in Sussex (Weir \& Catt, 1965; Perrin, 1971; Jeans, 2006). All samples were found to have a non-carbonate fraction dominated by smectite with subordinate illite. Also reported by Weir and Catt was the presence of euhedral alkali feldspar crystals in the fine silt fraction which were interpreted as being of authigenic origin. The samples examined in the present study have undergone mineralogical examination and some aspects of the data are presented in Jeans et al. (2014); additional data are presented below. Jeans et al. (2014) reported a similar mineralogy to that described by Weir and Catt and Perrin with a predominance of smectite or smectite-rich illite/ smectite but they also noted the presence of minor amounts of talc along with illite. Jeans et al. (2014) also reported the presence of minute euhedral alkali feldspar crystals in a small number of white chalk samples located between the Peacehaven and Meeching Triple Marls.

\section{METHODOLOGY}

Acid-insoluble residues of 65 samples were obtained by dissolving roughly crushed samples of chalk and marls in cold $1 \mathrm{~m}$ acetic acid followed by washing of the residue with deionized water. Residues were ground in an agate ball mill and dried at $105^{\circ} \mathrm{C}$. All powders were then dissolved using a lithium metaborate fusion by the method described in Wray \& Wood (1998). Quantification of major and abundant trace metals was achieved using a Thermo iCAP 6500 inductively coupled plasma-optical emission spectrometer; quantification of less abundant trace metals and the rare-earth elements (REE) was achieved using a Thermo $\mathrm{X}$ Series inductively coupled plasma-mass spectrometer. Calibration for both instruments was carried out using matrix matched multi-element standards constructed from traceable single element standards solutions. The laboratory in which this work was performed is accredited to ISO 17025 for this test (Testing Lab 2180). Five certified reference materials were tested in the same units of work as the samples and one of these reference materials, USGS Cody Shale (SCo-1), was used as the shale normalising standard for the rare-earth element plots (see discussion in Jarvis \& Jarvis, 1985). The expanded uncertainty of all measurements is less than $10 \%$ (relative).

The $<2 \mu \mathrm{m}$ acid-insoluble residue fraction was also separated and subjected to mineralogical analysis by X-ray diffraction (XRD). For details of the methodology adopted see Jeans et al. (2014).

\section{RESULTS AND DISCUSSION}

The results obtained for the acid insoluble residue major, trace and rare-earth elements are presented in Table 1. The data reveal a number of important features which provide additional insights into the development of marl seams; these would not have been readily seen from bulk rock samples due to their high, diluting carbonate content. In order to make chemical comparison between samples, elemental data were normalized to the $\mathrm{Al}_{2} \mathrm{O}_{3}$ value of the sample. This approach assumes that aluminium is primarily associated with clay minerals in the non-carbonate fraction. Normalisation of data to the aluminium value removes the inter-sample variability caused by

FIG. 1 (facing page). X-ray diffraction traces of glycerolated acid-insoluble residues from the $<2 \mu \mathrm{m}$ fraction of representative white chalks and marl seams. All samples are dominated by smectite or smectite-rich illite/smectite (peak centred on $\sim 18 \AA$ ) with subordinate illite (peaks at $10 \AA$ and $5 \AA$ ) and the low, variable presence of talc (peaks at $9.2 \AA$ and $3.06 \AA$ ). The $3.34 \AA$ peak is a mixture of illite and quartz. Visual analysis of peak shape and height indicate that the relative abundance of illite and smectite remain broadly constant throughout the section with the exception of the Old Nore Marl where the illite peak is notably smaller. Tescombe Marl 2 also has a slightly smaller illite peak than that seen in the white chalks and marls above and below. The remaining marl seams showed no apparent difference to the residue from the white chalks above and below. 


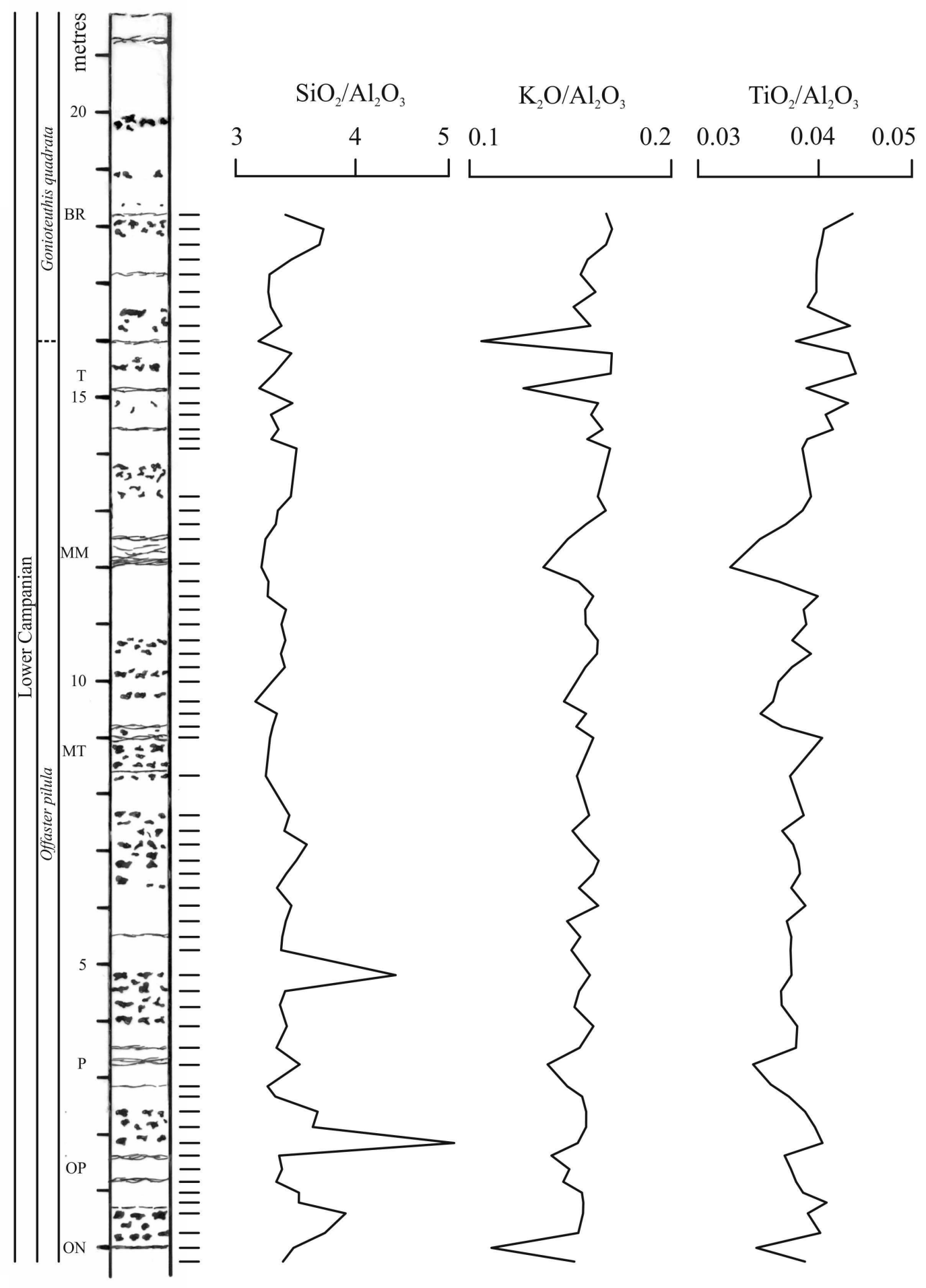


factors such as dilution by quartz which would otherwise hinder interpretation.

A representative selection of the $<2 \mu \mathrm{m}$ glycerolated acid insoluble residue mineralogical XRD tracings are presented in Fig. 1. All samples are dominated by smectite or smectite-rich illite/ smectite (peak centred on $\sim 18 \AA$ ) with subordinate illite (peak at $10 \AA$ ) and the low, variable presence of talc (peak at $9.2 \AA$ ). Visual analysis of peak shape and height indicate that the relative abundance of illite and smectite remain broadly constant throughout the section with the exception of the Old Nore Marl where the illite peak is notably smaller. Telscombe Marl 2 also has a slightly smaller illite peak than that seen in the white chalks and marls above and below. The remaining marl seams showed no apparent difference to the residue from the white chalks above and below at the resolution of our X-ray diffraction measurements.

\section{Major element data}

Stratigraphic plots of selected aluminium normalized elements are presented in Fig. 2. A plot of $\mathrm{SiO}_{2} / \mathrm{Al}_{2} \mathrm{O}_{3}$ is interpreted as reflecting variation in the quartz/clay ratio. It shows isolated, single sample spikes and also low magnitude increases, both of which have a broad association with the flint bands within the chalks. There is no increase in the $\mathrm{SiO}_{2} / \mathrm{Al}_{2} \mathrm{O}_{3}$ ratio associated with the presence of marl seams.

A plot of $\mathrm{K}_{2} \mathrm{O} / \mathrm{Al}_{2} \mathrm{O}_{3}$ is instructive in illustrating changes in the proportion of K-rich minerals in the non-carbonate fraction. Earlier mineralogical studies discussed above have demonstrated that potassium feldspar is rare or absent in the noncarbonate fraction and that the dominant K-bearing phase is the clay mineral illite. The reported presence of rare, small alkali feldspar crystals between the Peacehaven and Meeching Triple Marls (Jeans et al., 2014) does not influence the $\mathrm{K}_{2} \mathrm{O} / \mathrm{Al}_{2} \mathrm{O}_{3}$ plot.
Examination of the stratigraphic profile for $\mathrm{K}_{2} \mathrm{O}$ / $\mathrm{Al}_{2} \mathrm{O}_{3}$ shows that all prominent clay-rich marl beds with the exception of Telscombe Marl 1 and the Black Rabbit Marl (Fig. 2) are associated with a decrease in the $\mathrm{K}_{2} \mathrm{O} / \mathrm{Al}_{2} \mathrm{O}_{3}$ ratio. This is mimicked by a decrease in the $\mathrm{TiO}_{2} / \mathrm{Al}_{2} \mathrm{O}_{3}$ ratio. This pattern is interpreted as indicating that most if not all the marl seams have a slightly more smectite-rich noncarbonate mineralogy than that found in the overand underlying white chalks. This is partly supported by XRD mineralogical traces of the Old Nore Marl and Telscombe Marl 2, but for most of the other marls the XRD data are inconclusive (Fig. 1). Jeans et al. (2014) presented semiquantitative insoluble residue data for a number of fractions $(<0.2 \mu \mathrm{m}, 0.2-1 \mu \mathrm{m}$ and $1-2 \mu \mathrm{m})$ from selected samples which also adds some support to our conclusion in that the relative abundance of illite in the volumetrically dominant $0.2-1.0 \mu \mathrm{m}$ fraction is higher in the white chalk samples studied when compared to the marls. In the $<0.2 \mu \mathrm{m}$ fraction smectite dominates all samples whilst in the volumetrically minor $1-2 \mu \mathrm{m}$ fraction illite is more abundant. The absence of this feature in some of the very thin, minor marls is probably due to the relatively low abundance of non-carbonate material in these beds and hence a greater incorporation of 'white chalk' derived non-carbonate material at the preparation/laboratory dissolution stage. Bulk rock geochemical data from these samples typically gave $\mathrm{Al}_{2} \mathrm{O}_{3}$ values of 0.5 to 0.75 wt. $\%$, reflecting their low clay content. The change in $\mathrm{K}_{2} \mathrm{O}$ and $\mathrm{TiO}_{2} / \mathrm{Al}_{2} \mathrm{O}_{3}$ ratios between marl seams and white chalks implies that it is very unlikely that the marl seams were formed by syn-sedimentary or post depositional dissolution of the white chalk carbonate fraction, and that they are primary sedimentary features. The question as to whether the marl seams are derived from a different source is more difficult to answer as the slight change in elemental (and mineralogical) composition may be a reflection of the mode of transportation and/or the speed of transport from the source region to the site of

FIG. 2 (facing page). Stratigraphic plot of variation in $\mathrm{SiO}_{2} / \mathrm{Al}_{2} \mathrm{O}_{3}, \mathrm{~K}_{2} \mathrm{O} / \mathrm{Al}_{2} \mathrm{O}_{3}$ and $\mathrm{TiO}_{2} / \mathrm{Al}_{2} \mathrm{O}_{3}$ as found in acidinsoluble residues through the Peacehaven Stairs section. $\mathrm{SiO}_{2} / \mathrm{Al}_{2} \mathrm{O}_{3}$ data show subtle increases associated with many of the flint bands. $\mathrm{K}_{2} \mathrm{O} / \mathrm{Al}_{2} \mathrm{O}_{3}$ and $\mathrm{TiO}_{2} / \mathrm{Al}_{2} \mathrm{O}_{3}$ show subtle decreases within most marl seams; this is interpreted as a slight reduction in the proportion of potassium- and titanium-bearing minerals (predominantly illite) within the marl seams. ON: Old Nore Marl (PHS2), OP: Old Nore Pair (PHS 7, 9), PP: Peacehaven Marl (PHS15), MT: Meeching Triple Marls (PHS31, 32, 33), MM: Meeching Marls (pair) (PHS 44, 45), T: Telscombe Marls (PHS 54), BR: Black Rabbit Marl (PHS 65). 


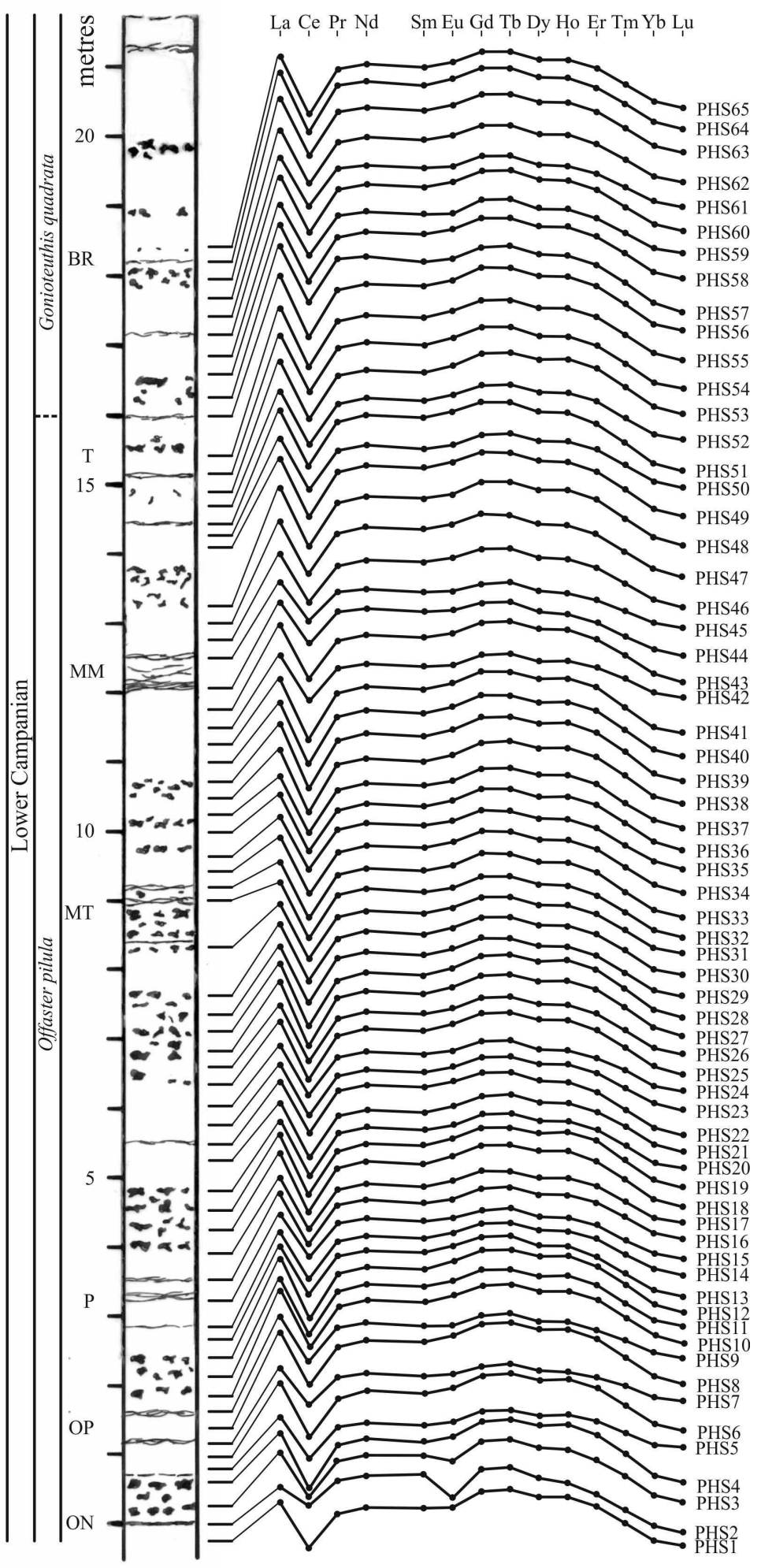


deposition. The elevated smectite content may also reflect the preferential formation of authigenic smectite within the marl layers, but we have no supporting evidence for this proposal. The only key exception to this discussion is the Old Nore Marl which is considered below.

\section{Rare-earth element profiles and trace element composition}

Previous studies of clay-rich beds in the Chalk have demonstrated the ability of the rare earth elements (REE) to differentiate between those of detrital provenance and those of a volcanogenic provenance (Wray, 1995, 1999; Wray \& Wood, 1998, 2002). The key differentiating factor has been the presence or absence of a negative europium $\mathrm{Eu}$ anomaly in plots generated by normalising $R E E$ data to that derived from an average shale (in this case USGS Reference Material Cody Shale, SCo-1). The anomaly is generated by the preferential uptake of Eu into feldspar minerals within the magma chamber and their subsequent loss from the melt during fractional crystallization. Rocks such as rhyolites derived from evolved magmas are invariably characterized by a significant negative Eu anomaly (Rollinson, 1993). Shale-normalized REE patterns of the acid-insoluble residue of all samples are presented stratigraphically in Fig. 3. Most samples display a very similar pattern comprising of a negative Ce anomaly, a slight enrichment in the middle $R E E$ and a gradual depletion in the heavy REE. Sample PHS 2 from within the Old Nore Marl displays broadly the same pattern but with a reduced $\mathrm{Ce}$ anomaly and, importantly, a marked negative Eu anomaly; a slight, negative Eu anomaly is also present in sample PHS 3, a chalk sample just above the Old Nore Marl. Using experience gleaned from previous studies of marls of Turonian and Coniacian age (Wray, 1999) we propose that the Old Nore Marl is volcanically derived; its higher smectite content means that it is best classified as a bentonite. The slight $\mathrm{Eu}$ anomaly present in sample PHS 3 either represents a residual tail of activity or, more likely, the upward reworking of non-carbonate material from the Old Nore Marl by bioturbating organisms. These are the only two marly samples which display these traits; all other marls display a profile which has previously been interpreted as indicating a detrital origin (Wray, 1999).

The use of acid-insoluble residues also enables the investigation of the REE profiles of the noncarbonate fraction of white chalks, something which has not been possible in previous studies. The white chalk residue profiles are near identical to that of the detrital marls and none of the white chalk profiles display a negative Eu anomaly (with the exception of PHS 3, as discussed above). This implies that there was little or no low-level or background volcanism occurring during the accumulation of the studied white chalk succession the Old Nore event was a distinct, time limited event.

Differentiation of the Old Nore Marl from the other insoluble residues can also be demonstrated using trace element plots. The igneous petrology plot of Pearce (1996) is often used to classify bentonites (e.g. Wray, 1999; Batchelor et al., 2003). Figure $4 \mathrm{a}$ shows a clear distinction between the Old Nore Marl (PHS 2) and other samples, with the adjacent sample PHS 3 plotting at an intermediate position. If the elements plotted are considered immobile then the plot implies that the Old Nore Marl is of rhyodacite to dacite composition, a broadly comparable composition to that of the Turonian-age bentonites of the Anglo-Paris Basin as discussed by Wray (1999). A plot of $\mathrm{Yb} v s$. Ta (Pearce et al., 1984) in Fig. 4b indicates that the Old Nore bentonite plots within the WPG field and thus has a within plate source. In both plots all the other detrital marl seams plot close to the mean value for Continental Crust (Rudnick \& Gao, 2003). This is coincidentally within the andesite/basalt

FIG. 3 (facing page). Stratigraphic plot of variation in shale-normalized rare earth element (REE) patterns as found in acid-insoluble residues through the Peacehaven Stairs section. Most patterns are very similar and display a negative Ce anomaly, a slight enrichment in the middle REEs and a gradual depletion in the heavy REEs. Notably different is sample PHS 2 (Old Nore Marl) which displays a reduced Ce anomaly and a distinct negative Eu anomaly, and PHS3 which has a reduced but still observable negative Eu anomaly. With reference to previous studies in older chalks the Old Nore Marl is considered to be a bentonite. ON: Old Nore Marl, OP: Old Nore Pair, PP: Peacehaven Marl, MT: Meeching Triple Marls, MM: Meeching Marls (pair), T: Telscombe Marls; BR: 
field but no inference is made as to this being their origin, it is an artefact of the use of an igneouspetrology-derived diagram to demonstrate the likely composition of the Old Nore Marl/bentonite. Their inclusion on the plot reinforces the observation that data obtained from the Old Nore Marl are atypical for a detrital sediment.

\section{Distant correlation and source of the Old Nore Marl}

The presence of a bentonite close to the Santonian-Campanian boundary is also observed in northern Germany. The marl M1 found in the Lagerdorf section is also considered to be a bentonite (Schonfeld et al., 1996) and the natural correlation compliant with the biostratigraphy is to
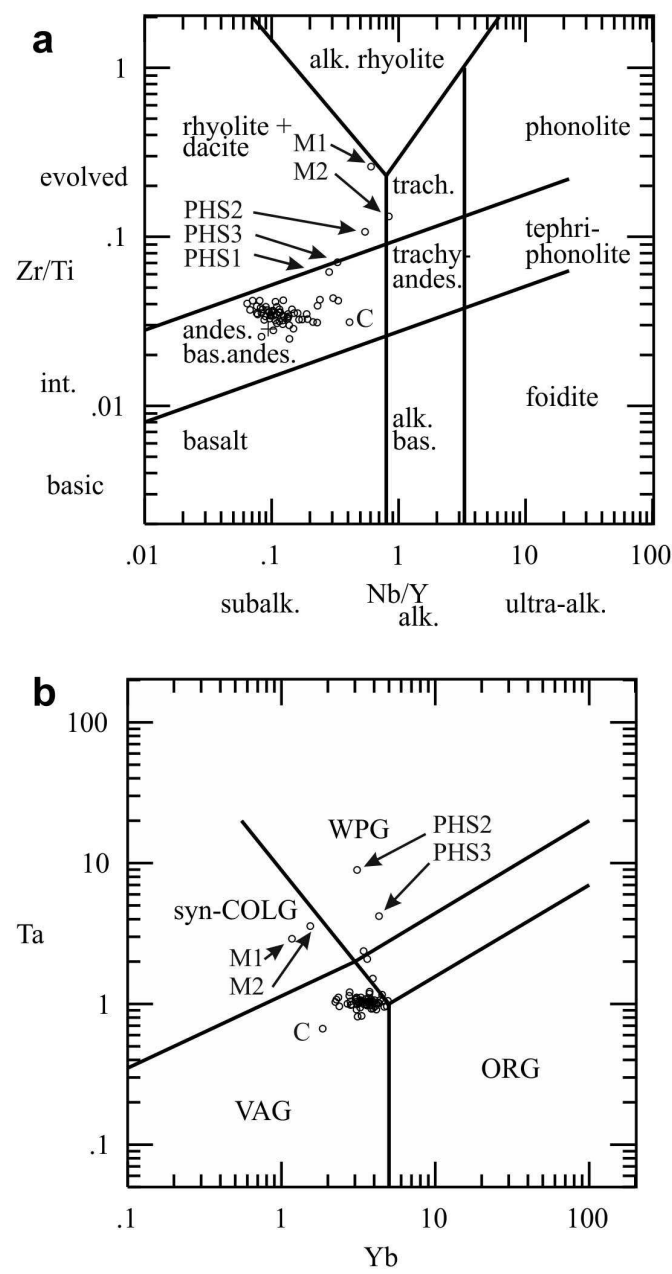

correlate the Old Nore Marl to M1 (C.J. Wood pers. comm.; Mortimore et al., 2001). Whilst trace element data show that the two beds have broadly the same composition there is an offset between M1 and Old Nore Marl (Figs 3a,b). This is not surprising given the geographic distance between the two sites and this phenomenon was also observed when comparing north German and southern England bentonites of Turonian age (Wray, 1999).

The source of bentonites in Cretaceous chalks was discussed by Wray (1999) and remains problematic with no clear candidate. Wray proposed that the source for bentonites of Turonian and Coniacian age was most likely to be associated with the early stages of rifting of the North Atlantic to the north west of the UK and this remains the case for the Campanian Old Nore Marl.

\section{CONCLUSIONS}

This work demonstrates that the provenance of noncarbonate material in early Campanian chalks varies. Non-carbonate material found in white chalks and most marl seams is considered to be of detrital origin, whilst the Old Nore Marl is volcanically derived and is best classified as a bentonite. This division is based primarily on chemical criteria that have been successfully applied to marl seams of Turonian and Coniacian

FIG. 4. (a) Acid-insoluble residue data plotted on the discrimination plot of Pearce (1996). Note that PHS 2 (Old Nore Marl) plots separately from the remaining samples and that samples PHS 1 and 3 immediately below and above the Old Nore Marl plot at a location between PHS 2 and the remaining samples. Although factors such as modification during transport and post depositional alteration must be considered, sample PHS 2 plots in the rhyolite/dacite field. Samples PHS 1 and 3 are interpreted as containing a proportion of bentonite due to bioturbation and reworking. There is no suggestion that the detrital beds are derived from an andesitic source and they plot close to the value for mean Continental Crust $(C)$ (Rudnick \& Gao, 2003). Also included are the results for bentonite M1 and the younger bentonite M2 from the north German succession (see Schonfeld et al., 1996). (b) Granite provenance plot after (Pearce et al., 1984). A plot of data from the Old Nore Marl (PHS2) indicates that it came from a within-plate source. VAG: volcanic-arc granite; ORG: ocean-ridge granite; WPG: within plate granite; syn-COLG: syn-collisional granite. 
age. Chemical analysis of acid-insoluble residues demonstrates that the detrital marls have a subtly different composition to that of white chalks, implying that they were not formed through the penecontemporaneous or diagenetic dissolution of white chalks. Trace element analysis of the Old Nore Marl implies that the original ash had an acidic, rhyodacite to dacite composition and is derived from a within plate source, most likely associated with the early stages of rifting of the North Atlantic, to the northwest of the UK.

\section{ACKNOWLEDGMENTS}

The authors would like to thank Lorna Dyer for her assistance with sample preparation procedures and Rory Mortimore for his guidance in the field. The authors would also like to acknowledge the very constructive comments offered by Harry Shaw and Jenny Huggett during the review process

\section{REFERENCES}

Batchelor R.A., Harper D.A.T. \& Anderson T.B. (2003) Geochemistry and potential correlation of Silurian (Telychian) metabentonites from Ireland and SW Scotland. Geological Journal, 38, 161-174.

Brydone R.M. (1914a) The Zone of offaster pilula in the south English Chalk: Part 1. Geological Magazine (Decade VI), 1, 359-369.

Brydone R.M. (1914b) The Zone of offaster pilula in the south English Chalk: Part 4, general conclusions. Geological Magazine (Decade VI), 1, 509-513.

Deconinck J.-F. \& Chamley H. (1995) Diversity of smectite origins in late Cretaceous sediments: Examples of chalks from northern France. Clay Minerals, 30, 365-379.

Dorn P. \& Bräutigam F. (1959) Hinweise auf oberkreidevulkanismus in NW-Deutschland. Abhandlungen der Braunschweigischen Wissenschaftlichen Gesellschaft, 11, 1-4.

Ernst G., Schmid F. \& Seibertz E. (1983) Eventstratigraphie im Cenoman und Turon von NWDeutschland. Zitteliana, 10, 531-554.

Jarvis I. \& Jarvis K.E. (1985) Rare-earth element geochemistry of standard sediments - a study using inductively coupled plasma spectrometry. Chemical Geology, 53, 335-344.

Jeans C.V. (2006) Clay mineralogy of the Cretaceous strata of the British Isles. Clay Minerals, 41, $47-150$.

Jeans C.V., Tosca N., Hu X.F. \& Boreham S. (2014) Clay mineral-grain size-calcite cement relationships in the Upper Cretaceous chalk, UK: A preliminary investigation. Clay Minerals, 49, xxx-xxx.
Mortimore R.N. (1986) Stratigraphy of the Upper Cretaceous White Chalk of Sussex. Proceedings of the Geologists' Association, 97, 97-140.

Mortimore R.N., Wood C.J. \& Gallois R.W. (2001) British Upper Cretaceous Stratigraphy. Joint Nature Conservation Committee, Peterborough, 558 pp.

Pacey N.R. (1984) Bentonites in the Chalk of central eastern England and their relation to the opening of the northeast Atlantic. Earth and Planetary Science Letters, 10, 48-60.

Pearce J.A. (1996) A user's guide to basalt discrimination diagrams. Pp. 79-113 in: Trace element Geochemistry of Volcanic rocks; Applications for Massive Sulphide Exploration, Short Course Notes (A.H. Bailes, E.H. Christiansen, A.G. Galley, G.A. Jenner, J.D. Keith, R. Kerrich, D.R. Lentz, C.M. Lesher, S.B. Lucas, J.N. Ludden, J.A. Pearce, S.A. Peloquin, R.A. Stern, W.E. Stone, E.C. Syme, H.S. Swinden, \& D.A. Wyman, editors). Geological Association of Canada, 12.

Pearce J.A., Harris N.B.W. \& Tindle A.G. (1984) Trace element discrimination diagrams for the tectonic interpretation of granitic rocks. Journal of Petrology, 25, 956-983.

Perrin R.M.S. (1971) The Clay Mineralogy of British Sediments. Mineralogical Society (Clay Minerals Group), London, 247 pp..

Rollinson H.R. (1993) Using Geochemical Data: Evaluation, Presentation, Interpretation. Longman Scientific \& Technical, Harlow, 352 pp.

Rudnick R.L. \& Gao S. (2003) Composition of the continental crust. Pp. 1-64 in: The Crust; Treatise on Geochemistry (R.L. Rudnick, editor), 3,Elsevier.

Schonfeld J., Schulz M.-G., McArthur J.M., Burnett J., Gale A.S., Hambach U., Hansen H.J., Kennedy W.J., Rasmussen K.L., Thirlwall M.F. \& Wray D.S. (1996) New results on biostratigraphy, palaeomagnetism, geochemistry and correlation from the standard section for the Upper Cretaceous White Chalk of northern Germany (Lägerdorf-KronsmoorHemmoor). Mitteilungen aus dem GeologischPaläontologischen Institut der Universität Hamburg, 77, 545-575.

Seibertz E. \& Vortisch W. (1979) Zur stratigraphie, petrologie und genese einer bentonit-lage aus dem oberen mittel-Turon (Oberkreide) des südöstlichen Münsterlandes. Geologische Rundschau, 68, 649-679.

Weir A.H. \& Catt J.A. (1965) The mineralogy of some Upper Chalk samples from the Arundel area, Sussex. Clay Minerals, 6, 97-110.

Wray, D.S. (1995) Origin of clay-rich beds in Turonian chalks from Lower Saxony, Germany - a rare earth element study. Chemical Geology, 119, 161-173.

Wray D.S. (1999) Identification and long-range correlation of bentonites in Turonian - Coniacian (Upper Cretaceous) chalks of northwest Europe. Geological 
Magazine, 136, 361-371.

Wray D.S. \& Wood C.J. (1995) Geochemical identification and correlation of tuff layers in Lower Saxony, Germany. Berliner Geowissenschaftliche Abhandlungen, E16.1, 215-226.

Wray D.S. \& Wood C.J. (1998) Distinction between detrital and volcanogenic clay-rich beds in TuronianConiacian Chalks of eastern England. Proceedings of the Yorkshire Geological Society, 52, 95-105.

Wray D.S. \& Wood C.J. (2002) Identification of a new bentonite in sediments of mid-Turonian age from Lower Saxony, Germany and its correlation within
NW Europe. Austrian Academy of Science Series: Schriftenreihe der Erdwissenschaftlichen Kommissionen, 15, 47-58.

Wray D.S., Kaplan U. \& Wood C.J. (1995) Tuffvorkommen und ihre bio- und eventstratigraphie im Turon des Teutoburger Waldes, Der Egge und Des Haarstrangs. Geologie und Paläontologie in Westfalen, 37, 1-53.

Wray D.S., Wood C.J., Ernst G. \& Kaplan U. (1996) Geochemical subdivision and correlation of clay-rich beds in Turonian sediments of northern Germany. Terra Nova, 8, 603-610. 